\title{
Pendampingan Peningkatan Kemampuan Menulis Penelitian Tindakan Kelas Guru Bahasa Inggris di Kabupaten Solok
}

\author{
Veni Roza ${ }^{1}$, Absharini Kardena ${ }^{2}$ \\ $1^{\text {st }}$ IAIN Bukitinggi, Indonesia, veniroz_501@yahoo.com \\ $2^{\text {nd }}$ IAIN Bukitinggi, Indonesia, absharinikardena@yahoo.co.id
}

2021 by the authors. Submitted for possible open access publication under the terms and conditions of the Creative Commons Attribution-ShareAlike 4.0 International License-(CC-BY-SA) (https://creativecommons.org/licenses/by-sa/4.0/)

di) DOI: $\underline{\text { http: }: / \text { dx.doi.org } / 10.30983 / \text { dedikasia.vlil.4630 }}$

\begin{tabular}{|c|c|}
\hline ARTICLE INFO & $\begin{array}{c}\text { ABSTRACT } \\
\end{array}$ \\
\hline Submit : 05 Januari 2021 & Increasing teacher competence should be carried out continuously. It is \\
\hline Revised : 02 April 2021 & aimed to increase the professionalism of teachers in the field of teaching. \\
\hline Accepted : 30 Juni 2021 & $\begin{array}{l}\text { One of ways that can be done to improve teacher pedagogical } \\
\text { competence is by conducting Classroom Action Research (CAR). This }\end{array}$ \\
\hline $\begin{array}{l}\text { Keywords: } \\
\text { pendampingan, penelitian tindakan } \\
\text { kelas. }\end{array}$ & $\begin{array}{l}\text { research aims to improve the approach in teaching so that the results of } \\
\text { student achievement can be improved. However, the implementation of } \\
\text { CAR is often being an obstacle for teachers because of their lack of } \\
\text { knowledge related to the implementation of CAR, which starts from the } \\
\text { preparation of proposals, conducting research, to reporting research. It } \\
\text { becomes a real urgency for teachers to get assistance in preparing CAR } \\
\text { proposals as an initial step in implementing CAR in schools. An } \\
\text { assistance for writing CAR proposals is a necessity for teachers so that } \\
\text { the teachers have a strong basis for implementing CAR properly and } \\
\text { correctly. Therefore, this assistance is carried out to improve the ability of } \\
\text { teachers to write CAR proposals so that the final goal of implementing a } \\
\text { good CAR can be realized. }\end{array}$ \\
\hline
\end{tabular}

International License-(CC-BY-SA)

(https://creativecommons.org/licenses/by-sa/4.0/)

This is an open access article under the CC-BY-SA license

do) $h$ ttp:://dx.doi.org $/ 10.30983 /$ dedikasia.vlii.4630

\section{Introduction}

Semenjak terealisasinya sertifikasi guru secara bertahap yang dimulai tahun 2007 ([1]dan [2]), pengetahuan tentang penelitian tindakan kelas merupakan salah satu komponen yang menjadi indikator terlaksananya salah satu materi standar isi dalam pencapaian kurikulum di sekolah pendidikan dasar dan menengah. PTK yang sebelumnya kurang mendapat perhatian dalam keseluruhan tugas guru, dijadikan pengetahuan yang harus diimplementasikan dalam usaha meningkatkan mutu pembelajaran, terutama untuk mengatasi permasalahan pembelajaran yang dilaksanakan secara reflektif.

Sebagai orang yang seyogyanya profesional, seorang guru tidak hanya dituntut memiliki kompetensi yang tinggi di bidang bahan ajar, lebih jauh dia juga harus trampil dan cakap menyampaikannya kepada peserta didik sehingga pesan yang disampaikan sesuai dengan misi yang diharapkan. Dengan kata lain guru juga diharapkan mampu membimbing dan mengarahkan siswa dalam menapaki jalur pendidikannya. 
Hal ini termaktub dalam Undang-Undang Republik Indonesia No.14 pasal 1 ayat 1, tahun 2005, yang menyatakan bahwa guru adalah pendidik profesional dengan tugas utama mendidik, mengarahkan, menilai dan mengevaluasi peserta didik pada pendidikan anak usia dini jalur pendidikan formal, pendidikan dasar, dan menengah. Selanjutnya pasal 10 ayat 1, UU no.14 tahun 2005 menyatakan bahwa setiap guru seharusnya memiliki 4 kompetensi yakni kompetensi pedagogis, kompetensi kepribadian, kompetensi sosial, dan kompetensi profesional. Dengan kata lain, seorang guru tidak hanya pintar mengajar atau memiliki kemampuan pedagogis, akan tetapi juga memiliki kepribadian yang baik yang mencerminkan karakter seorang pendidik, pandai bersosialisasi baik di sekolah maupun di masyarakat, serta mampu menciptakan inovasi-inovasi terbaru dalam proses belajar mengajar, atau profesional di bidangnya masing-masing.

Guru bahasa Inggris, sebagai guru mata pelajaran, juga merupakan pendidik yang memiliki kewajiban yang sama dengan guru-guru lainnya. Setiap guru bahasa Inggris diharapkan profesional di bidangnya, menghasilkan ide-ide baru dalam meningkatkan kemampuan terkait bidang pengajaran bahasa Inggris.Salah satu tolok ukur guru profesional adalah guru yang mampu memahami tuntutan kurikulum, mampu menyelenggarakan pengajaran yang bermuara pada tujuan pembelajaran dan mampu berkreasi dan berinovasi khususnya dalam pola pembelajaran[3].

Akan tetapi, ketika mengajarkan bahasa Inggris, tidak jarang para guru menemukan kesulitan dalam proses belajar mengajar di kelas. Selain karena bahasa Inggris merupakan bahasa asing bagi peserta didik di Indonesia, guru-guru juga mengalami kesulitan dalam menerapkan metode pembelajaran yang cocok dengan hakekat materi ajar dan keadaan mayoritas peserta didik. Selain itu, bila ada permasalahan yang terkait dengan proses belajar mengajar, guru-guru kesulitan menemukan solusi yang tepat untuk permasalahan tersebut.

Kesulitan-kesulitan ini seringkali dihadapi oleh guru-guru bahasa Inggris di beberapa daerah tertentu di Sumatera Barat, salah satunya di Kabupaten Solok.Permasalahan yang paling sering dialami, salah satunya terkait dengan usaha mengembangkan kemampuan mengajar bahasa Inggris di kelas.Usaha ini tentunya terkait dengan kinerja guru yang dituntut untuk selalu tampil profesional.

Salah satu cara yang dapat dilakukan oleh guru-guru bahasa Inggris ini untuk meningkatkan profesionalitas sebagai tenaga pendidik adalah dengan cara melakukan penelitian yang terkait dengan kondisi kelas masing-masing[4]. Penelitian ini dikenal dengan penelitian tindakan kelas (PTK).Penelitian jenis ini memberikan kesempatan kepada para guru, termasuk guru bahasa Inggris, untuk menganalisis kekurangan dan kelebihan suatu sistem pembelajaran, sehingga dapat secara aktif memperbaiki dan meningkatkan mutu pelajaran[5]. 
Secara ringkas, pada salah satu poin dari Permendiknas No.16 tahun 2007 tentang standar kompetensi guru, dinyatakan bahwa seorang guru harus mampu melakukan tindakan reflektif untuk peningkatan kualitas pembelajaran. Tindakan reflektif ini dapat diberikan melalu penelitian tindakan kelas sebagai wadahnya[6]. Melalui penelitian ini, tindakan reflektif yang mungkin diberikan antara lain melakukan kegiatan refleksi terhadap pelajaran yang telah dilaksanakan, menggunakan hasil refleksi sebagai bahan pertimbangan dalam mengembangkan pelajaran dan meningkatkan kualitas pembelajaran berdasarkan hasil pertimbangan tersebut[7].

Selain itu, apabila guru-guru secara efektif mampu melaksanakan penelitian tindakan kelas, tidak hanya membantu dalam kualitas pengajaran, guru-guru pun akan terbantu dalam peningkatan angka kredit sebagai ketentuan naik pangkat atau golongan. Dengan melakukan penelitian tindakan kelas, guru-guru secara tidak langsung juga akan menulis karya ilmiah, yang tentu saja memiliki poin khusus dalam angka kredit kenaikan golongan. Selain itu, penulisan karya ilmiah dalam bentuk laporan hasil PTK saat ini menjadi satu persyaratan khusus yang wajib dipenuhi oleh guru untuk proses naik pangkat atau golongan. Jika sebelumnya, penulisan karya ilmiah dalam bentuk PTK menjadi suatu pilihan, saat ini hal itu telah menjadi salah stau persyaratan wajib bagi para guru.Secara gamblang dapat dikatakan bahwa, melakukan penelitian tindakan kelas memberikan keuntungan menyeluruh bagi guru.

Yang menjadi permasalahan adalah sebagian besar guru bahasa Inggris di madrasah Kabupaten Solok belum memperoleh ilmu secara praktis dalam melakukan PTK, bahkan ada yang sama sekali belum mengenal istilah PTK. Walaupun ada beberapa orang guru bahasa Inggris yang sudah mengenal PTK, pada dasarnya hanya sebatas mengetahui, belum sampai pada tahap implementasinya. Karenanya, pengetahuan tersebut belum terlihat dikembangkan kepada teman-teman sejawatnya.

Secara faktual ditemukan bahwa guru-guru bahasa Inggris Madrasah yang bertugas khususnya di Kabupaten Solok masih belum memahami bagaimana cara melakukan penelitian tindakan kelas. Padahal sudah jelas upaya ini mampu membantu guru dalam memecahkan berbagai permasalahan khususnya yang terkait dengan mutu pengajaran.Oleh karena itu, tentu perlu adanya usaha dari berbagai pihak untuk memberikan pembinaan khusus kepada guru-guru ini, terkait dengan pelaksanaan penelitian tindakan kelas.

Berdasarkan analisis situasi di atas, upaya yang akan diberikan untuk mengatasi permasalahan ini adalah melalui pelatihan penelitian tindakan kelas bagi guru Madrasah di Kabupaten Solok. Wawancara yang dilakukan mengindikasikan bahwa guru-guru bahasa Inggris Madrasah di Kabupaten Solok sering menemukan kesulitan dalam merumuskan solusi permasalahan yang terkait dengan proses belajar mengajar di kelas. Mereka terkesan bingung untuk menentukan langkah yang harus dilakukan karena kurangnya pemahaman tentang pelaksanaan penelitian tindakan 
kelas.Kalaupun ada beberapa guru yang mengetahui tentang penelitian tindakan kelas, pengetahuan saja tanpa dibarengi dengan aplikasinya belumlah cukup sehingga sering kali ketika berkeinginan melakukan penelitian tindakan kelas ini, menimbulkan kebingungan dan niat tersebut akhirnya diurungkan.

Tingginya tingkat kerumitan pembuatan PTK yang dialami para guru madrasah ini memicu timbulnya kesalahan guru dengan melakukan tindakan yang melanggar aturan akademis, yaitu melakukan plagiarisme demi memenuhi tuntutan pembuatan PTK dalam proses kenaikan pangkat atau golongan. Hal ini menjadi salah satu masalah serius dalam dunia pendidikan yang notabene disebabkan oleh kurangnya pengetahuan guru mengenai konsep teoritis dan praksis dalam implementasi PTK.

Untuk dapat melakukan penelitian tindakan kelas, guru-guru harus memahami konsep dasar penelitian tindakan kelas, mencari akar permasalahan yang dapat diselesaikan sehingga solusi yang diharapkan dapat diperoleh.Untuk itu, guru-guru semestinya memahami teknik-teknik pembelajaran mutakhir yang sesuai dengan setiap jenis bahan ajar, kemudian disusun dalam rancangan proposal yang sistematis[8].

Menyadari fakta tersebut, penulis perlu memberikan layanan kepada masyarakat guru dalam bentuk kegiatan pendampingan peningkatan kemampuan menulis PTK guru bahasa Inggris madrasah. Diharapkan hal ini nantinya dapat membantu guru-gurtu tersbeut untuk mengatasi permasalah yang dihadapi dalam kelas melalui pelaksanaan PTK. Selain itu, diharapkan pula adanya peningkatan kemampuan guru dalam penulisan karya ilmiah, yang nantinya dapat berkontribusi dalam peningkatan kualitas para guru.

Kegiatan pengabdian ini bertujuan untuk meningkatkan kemampuna menulis PTK guru bahasa inggris madrasah di Kab. Solok. Kegiatan ini diharapkan mampu memberikan dampak positif terhadap peningkatan kemampuan guru untuk menghasilkan karya ilmiah, khususnya penelitian tindakan kelas.

\section{Literature Review}

Penelitian tindakan kelas merupakan pilihan yang menarik bagi peneliti guru, staf administrasi sekolah, dan pemangku kepentingan lainnya dalam lingkungan belajar mengajar[9]. Secara khusus, penelitian tindakan kelas dalam pendidikan dapat didefinisikan sebagai proses mempelajari situasi sekolah untuk memahami dan meningkatkan kualitas proses edukatif. Ini memberi para praktisi pengetahuan dan pemahaman baru tentang bagaimana meningkatkan praktik pendidikan atau menyelesaikan masalah signifikan di kelas dan sekolah[3]. Penelitian tindakan kelas menggunakan 
proses yang sistematis dan bersifat serta menawarkan banyak peluang yang menguntungkan bagi para profesional yang bekerja dalam profesi guru. Peluang ini termasuk memfasilitasi pengembangan profesional pendidik peningkatkan pemberdayaan guru, dan menjembatani kesenjangan antara penelitian dan praktik[10][11].

Dalam pendidikan, tujuan utama penelitian tindakan kelasadalah menentukan cara untuk meningkatkan kualitas kehidupan peserta didik. Pada saat yang sama, penelitian tindakan kelasdapat meningkatkan kehidupan para profesional yang bekerja dalam sistem pendidikan. Sebagai ilustrasi, penelitian tindakan kelas telah secara langsung dikaitkan dengan pertumbuhan dan perkembangan profesional guru[12]. Penelitian tindakan kelas(a) membantu guru mengembangkan pengetahuan baru yang berhubungan langsung dengan kelas mereka, (b) mempromosikan pengajaran dan pemikiran reflektif, (c) memperluas repertoar pedagogis guru, (d) menempatkan guru bertanggung jawab atas keahlian mereka, (e) memperkuat hubungan antara praktik dan prestasi siswa, (f) menumbuhkan keterbukaan terhadap ide-ide baru dan mempelajari hal-hal baru, dan (g) memberi guru kepemilikan praktik yang efektif. Selain itu, lokakarya penelitian tindakan kelasdapat digunakan untuk menggantikan guru tradisional yang tidak efektif pelatihan inservice[13].

Tujuan penelitian tindakan di sekolah dan kelas secara luas terbagi dalam lima kategori[14]. Pertama, ini adalah sarana untuk mengatasi masalah yang didiagnosis dalam situasi tertentu, atau meningkatkan dalam keadaan tertentu. Kedua, ini adalah sarana untuk membekali guru dengan keterampilan dan metode baru, mempertajam daya analisisnya dan meningkatkan kesadaran dirinya. Ketiga, ini adalah sarana untuk memasukkan pendekatan tambahan atau inovatif untuk mengajar dan belajar ke dalam sistem yang sedang berjalan yang biasanya menghambat inovasi dan perubahan. Keempat, merupakan sarana untuk meningkatkan komunikasi yang biasanya buruk antara guru praktik dan peneliti akademis. Kelima, merupakan sarana untuk memberikan alternatif yang lebih baik daripada pendekatan yang lebih subjektif untuk pemecahan masalah di kelas. Selain itu, gagasan lain dari Nur (2001) yang menyatakan lima tujuan penelitian tindakan kelas lainnya. Pertama, penelitian tindakan kelas berkontribusi pada teori dan basis pengetahuan yang dibutuhkan untuk meningkatkan praktik[15]. Kedua, mendukung pengembangan profesional praktisi dengan membantu mereka menjadi lebih kompeten dalam memahami dan memanfaatkan temuan penelitian dan melakukan penelitian sendiri bila diperlukan. Ketiga, membangun sistem jejaring kolegial karena terkadang melibatkan beberapa pendidik, bahkan siswa dan orang tua, bekerja sama. Keempat, membantu praktisi mengidentifikasi masalah dan mencari solusi secara sistematis. Kelima, dapat digunakan di semua jenjang dan di semua bidang pendidikan, seperti sarana in-service training bagi kepala sekolah. Meskipun penjelasan para ahli di atas tampak berbeda dalam bentuk pernyataan, namun esensi dari gagasan tersebut sangat mirip.

Penelitian tindakan kelas dilakukan melalui satu siklus dan dirancang dalam empat langkah. Penelitian dimulai dengan merencanakan suatu tindakan. Kemudian rencana tersebut 
diimplementasikan sebagai tindakan di kelas dan tindakan tersebut kemudian diamati[8]. Refleksi dilakukan untuk menganalisis data yang diperoleh selama tindakan. Kebanyakan model menyajikan penelitian tindakan sebagai siklus, dimulai dengan pertanyaan dan diakhiri dengan lebih banyak pertanyaan. Gambar di atas dimaksudkan untuk menangkap sifat siklus penelitian tindakan kelas. Strickland (1987:760) membahas urutan berikut: 1) mengidentifikasi isu, kepentingan atau masalah; 2) mencari ilmu; 3) merencanakan suatu tindakan; 4) melaksanakan tindakan; 5) mengamati tindakan; 6) merefleksikan pengamatan Anda; 7) merevisi rencana. Sejalan dengan Strickland, Borg, Gall dan Gall (1993: 392-394) menjelaskan bahwa ada tujuh langkah penelitian tindakan. Pertama, identifikasi pertanyaan terkait kelas yang ingin Anda teliti. Pertanyaan yang baik dapat mencakup "Apakah siswa saya lebih terlibat ketika mereka bekerja secara individu atau ketika mereka bekerja dalam kelompok?" atau "Apakah penelitian komputer membantu siswa memahami materi dengan lebih baik?" Kedua, periksa setiap penelitian yang berlaku untuk pertanyaan Anda. Misalnya, Anda dapat melihat studi tentang dampak teknologi pada pembelajaran. Ketiga, pilih desain pengajaran yang paling efektif dalam menjawab pertanyaan penelitian Anda. Misalnya, Anda dapat mengajar Bab 1 menggunakan satu metode tertentu, mengajar Bab 2 menggunakan metode lain, dan kemudian memeriksa perbedaan nilai dari kedua bab tersebut. Ini bukan eksperimen terkontrol, dan Anda tidak akan dapat membuktikan sesuatu yang berbeda, tetapi ini akan memberi Anda gambaran tentang jawaban. Keempat, kumpulkan data yang Anda perlukan untuk membantu menjawab pertanyaan penelitian Anda, seperti nilai siswa, hasil survey. Pastikan untuk mencatat semua yang Anda lihat atau dengar yang berhubungan dengan pertanyaan Anda. Kelima, menganalisis data yang telah Anda kumpulkan untuk sampai pada suatu kesimpulan. Anda dapat membuat grafik atau tabel nilai ujian, mengkategorikan berbagai anekdot atau membuat garis waktu beranotasi selama proses analisis. Keenam, terapkan strategi berdasarkan hasil Anda. Jika Anda menemukan bahwa strategi yang sudah Anda gunakan sangat membantu, strategi baru hanya akan membangun apa yang sudah Anda lakukan. Namun, jika Anda menemukan bahwa cara mengajar alternatif lebih efektif, Anda dapat melakukan brainstorming berbagai cara untuk mempraktikkan metode pengajaran tersebut. Ketujuh, bagikan penelitian Anda dengan rekan kerja dan orang lain yang mungkin tertarik. Diskusikan apa yang telah Anda temukan di rapat tim atau bahkan selama istirahat makan siang Anda. Sebagai alternatif, sebutkan kepada kepala sekolah dan sarankan agar dipublikasikan ke seluruh staf. Sebagai kesimpulan, penelitian tindakan kelas mengikuti serangkaian langkah yang berulang. Menyelesaikan siklus pertama, kemudian siklus dimulai sekali lagi, dengan revisi dimasukkan ke dalam tindakan baru, yang diamati dengan sendirinya, dan seterusnya. Proses ini memungkinkan guru yang ingin menyelidiki peristiwa di kelas mereka sendiri untuk mengambil langkah-langkah konstruktif menuju pemecahan masalah segera, secara sistematis merefleksikan hasilnya. Dengan demikian tujuan penelitian tindakan kelas adalah mencapai pemahaman lokal dan mengembangkan solusi yang layak untuk masalah. 


\section{Bentuk kegiatan}

1.Pengamatan Lapangan. Pelaksanaan kegiatan pendampingan peningkatan menulis PTK guru bahasa inggris madrasah ini dimulai dengan pengamatan lapangan terhadap guru-guru di MTsN 2 Kab. Solok, sehingga dapat diketahui kebutuhan dan permasalahan mitra. Pelaksanaan pengamatan lapangan ini selama dua hari, yaitu pada tanggall8-19 Mei 2018.

Dari pengamatan lapangan yang dilakukan selama 2 hari, diperoleh hasil sebagai berikut:

a. Permasalahan yang dihadapi guru-guru bahasa inggris dalam penulisan PTK terkait dengan beberapa hal, yaitu:

1.) Persepsi bahwa "saya bukan penulis"

2.) Kesulitan memulai menulis

3.) Kesulitan mengakhiri tulisan

4.) Merasa tidak mampu menulis hal-hal hebat

5.) Tidak punya ide orisinal

6.) Takut salah

7.) Dihantui panjangnya tulisan

8.) Rasa rendah diri dan tidak mampu

9.) Tugas guru yang banyak ditambah dengan urusan pribadi yang kompleks.

b. Kebutuhan guru bahasa inggris untuk memiliki kemampuan menulis PTK yang baik sebagai salah satu prasyarat mengajukan kenaikan pangkat. Hal ini menjadi sangat krusial bagi-guru tersebut sehingga mereka dapat menghindari plagiat dalam penulisan PTK.

\section{Pelaksanaan Pendampingan PTK.}

Pelaksanaan pendampingannya adalah selama tiga hari, yaitu pada tanggal 14-16 Agustus 2018, dengan perhitungan waktu kegiatan pelatihan = hari pertama 3 jam (14.00-17.00 WIB) + hari kedua 5 jam (09.00-12.00 WIB, disambung jam 14.00-16.00 WIB) + hari ketiga 4 jam (08.00-12.00 WIB)

Adapun kegiatan pelaksanaan pelatihannya adalah sebagai berikut:

a. Pada hari pertama tanggal 14 Agustus 2018, kegiatan berlangsung dari jam 08.00 s.d. jam 16.00 WIB, yang didahului dengan laporan ketua panitia, dan sambutan kepala Sekolah MTsN 2 Kab. Solok sekaligus membuka acara pelatihan tersebut, setelah itu di adakan Pre-Test untuk mengetahui tingkat pemahaman peserta, baru setelah pre-test, dilaksanakan pelatihan penulisan karya ilmiah (PTK) dimulai, dengan narasumber ibu Hj. Makhdalena, S.Pd dengan materi Pemahaman tentang Karya Ilmiah (PTK).

b. Pada hari kedua tanggal 15 Agustus 2018, kegiatan berlangsung dari jam 09.00 s.d. jam 16.00 WIB pelatihan Penelitian Tindakan Kelas dan permasalahanya dengan narasumber ibu $\mathrm{Hj}$. Makhdalena, S.Pd.

c. Pada hari ketiga pelaksanaan kegiatan pendampingan peningkatan menulis PTK, pada tanggal 16 Agustus 2018, kegiatan berlangsung dari jam 08.00 s.d jam 12.00 WIB, dimulai dengan 
Post-test dan dilanjutkan dengan materi Implementasi (praktik langsung) membuat PenelitianTindakan Kelas (PTK) yang dimulai dengan pembuatan judul PTK, Daftar Isi PTK, dan isi (batang tubuh) PTK dengan narasumber Ibu Hj. Makhdalena, S.Pd.

\begin{tabular}{|c|c|c|c|}
\hline NO & KEGIATAN & PELAKSANAAN & $\begin{array}{l}\text { JUMLAH } \\
\text { JAM }\end{array}$ \\
\hline 1 & $\begin{array}{l}\text { Pembukaan acara } \\
\text { Pre-test penulisan PTK } \\
\text { Pelatihan penulisan PTK } \\
\text { Tgl. } 14 \text { Agustus } 2018\end{array}$ & 1 hari $x 3$ oj & 3 jam \\
\hline 2 & $\begin{array}{l}\text { Pelatihan penulisan PTK dan } \\
\text { permasalahnnya } \\
\text { Tggl. } 15 \text { Agustus } 2018\end{array}$ & 1 hari $x 5$ oj & $5 \mathrm{jam}$ \\
\hline 3 & $\begin{array}{l}\text { Post-test } \\
\text { Praktik pembuatan proposal PTK } \\
\text { Tgl. } 16 \text { Agustus } 2018\end{array}$ & 1 hari $x 4$ oj & 4 jam \\
\hline & Jumlah Jam Kegiat & & $12 \mathrm{jam}$ \\
\hline
\end{tabular}




\section{Diseminasi hasil.}

Diseminasi hasil diperlukan guna dapat mengetahui sampai sejauh mana kegiatan ini berjalan sesuai dengan target dan luaran yang ingin dicapai. Dari diseminasi hasil yang di laksanakan selama satu hari, yakni tanggal 1 September 2018diperoleh hasil kegiatan pendampingan peningkatan menulis PTK sebagai berikut::

1) Pelaksanaan kegiatan pelatihan ini selain meningkatkan kemampuan dan kemauan guru-guru untuk menulis karya ilmiah (PTK) yang baik dan benar, juga merupakan kebutuhan yang selama ini sedang ditunggu-tunggu oleh para guru-guru bahasa inggris madrasah di Kab. Solok.

2) Kegiatan pelatihan penulisan karya ilmiah (PTK) ini mendapatkan tanggapan yang positif dari guru-guru, untuk itu sebagai evaluasi, perlu dikembangkan pelaksanaannya di masa yang akan datang di lokasi kelompok guru-guru yang berada di sekolah-sekolah yang sangat membutuhkan pelatihan ini.

\section{Pelaporan hasil kegiatan.}

Penyusunan pelaporan hasil kegiatan pendampingan penulisan karya Ilmiah (PTK) sedang berlangsung hingga hari ini. Pelaksanaan penyusunan pelaporan hasil kegiatan ini dilakukan di kampus II IAIN Bukittinggi untuk merampungkan laporan pelaksanaan pendampingan ini, yaitu membuat laporan hasil pelaksanaan.

\section{Results}

Kegiatan pengabdian yang dilakukan terkait dengan peningkatan kemampuan menulis PTK bagi guru bahasa inggris di kabupaten Solok, lebih tepatnya dilaksanakan di MTsN 2 Kab. Solok mengikutsertakan guru bahasa inggris sebanyak 10 orang. Guru-guru tersebut mengikuti kegiatan pendampinan penulisan PTK ini selama 3 hari yakni 14-16 Agustus 2018.

Dalam pelaksanaan kegiatan pengabdian, data yang diperoleh dilakukan melaui dua tahap, yakni pretest dan post-test penulisan proposal PTK. Kegiatan pre-test dilaksanakan pada hari pertama pengabdian yakni 14 Agustus 2018. Tahap pre-test ini dilakukan untuk menganalisis kebutuhan dan permasalahan guru dalam menulis proposal PTK. Data dari kegiatan pre-test ini dijadikan landasan acuan dalam menilai kemampuan menulis proposal PTK guru bahasa inggris sebelum diberikan kegiatan pendampingan.

Disamping pre-test, tahap kedua melibatkan post-test yang dilaksanakan pada tanggal 16 Agustus 2018 dimana pada hari terakhir terserbut guru kembali diminta untuk menulis proposal PTK sebagai bentuk perbaikan penulisan PTK yang telah dibuat pada hari pertama. Guru diberi kesempatan 
untuk menulis ulang proposal PTK atau merevisi proposal yang telah mereka tulis pada hari pertama. Kegiatan post-test ini akan menjadi Patoka peningkatan kemampuan guru dalam menulis proposal PTK setelah diberikan pendampingan selama 3 hari.

Data yang diperoleh dari kegiatan pre-test dan post-test diukur dengan menggunakan standar penulisan proposal PTK[16]. Berikut uraian data yang diperoleh dari kegiatan pre-test dan post-test:

1. Kegiatan pre-test

Dari 10 orang guru yang mengikuti kegiatan pre-test diperoleh data sebagai berikut:

a. Pada awal kegiatan, para peserta merasa rendah diri dan merasa tidak akan mampu mengikuti kegiatan secara utuh dan menghasilkan satu karya tulis ilmiah hasil PTK.

b. Wawasan mereka tentang metodologi penelitian masih kurang

c. Kemampuan mereka dalam melakukan PTK masih rendah

d. Penguasaan mereka atas landasan konseptual dan teori-teori yang digunakan dalam penelitian sangat minim

e. Kemampuan mereka dalam menggunakan ICT masih rendah sehingga akses mereka terhadap informasi yang bersumber dari internet sangat minim

f. Kemampuan menulis yang menggunakan kaidah ilmiah masih rendah.

g. Daya juang mereka untuk mencapai hasil terbaik, perlu ditingkatkan

h. Daya serap terhadap materi pelatihan dan daya tangkap terhadap arahan pendamping belum memuaskan.

i. Penyelesiaan tugas-tugas relatif lamban dan cukup bervariasi waktu penyelesaiannya.

j. Ada beberapa peserta yang belum terampil menulis dengan menggunakan komputer.

diketahui bahwa ada beberapa bentuk permasalahan yang dimiliki guru dalam menulis proposal PTK. Permasalahan tersebut dapat dilihat pada table berikut:

Table 1. Permasalahan Guru Dalam Menulis Proposal PTK

\begin{tabular}{clcc}
\hline No & \multicolumn{1}{c}{ Jenis Masalah } & $\begin{array}{c}\text { Jumlah } \\
\text { permasalahan yang } \\
\text { muncul }\end{array}$ & $\begin{array}{c}\text { Persentase } \\
\text { permasalahan yang } \\
\text { muncul }\end{array}$ \\
\hline $\mathbf{l}$ & $\begin{array}{l}\text { Belum adanya permasalahan yang } \\
\text { spesifik dalam latar belakang masalah } \\
\text { sesuai judul yang diangkat }\end{array}$ & 6 & $60 \%$ \\
2 & $\begin{array}{l}\text { Tidak relevan antara judul dengan } \\
\text { masalah yang diuraikan dalam latar } \\
\text { belakang }\end{array}$ & 1 & $10 \%$ \\
\hline 3 & $\begin{array}{l}\text { Belum adanya penjelasan ilmiah } \\
\text { tentang alasan pemilihan teknik } \\
\text { pengajaran sebagai solusi terhadap } \\
\text { masalah yang ada }\end{array}$ & 6 & $60 \%$ \\
\hline & Minimnya landasan teoritis yang & 10 & $100 \%$ \\
\hline
\end{tabular}




\begin{tabular}{llll}
\hline 5 & $\begin{array}{l}\text { digunakan dalam proposal } \\
\text { Masih minimnya uraian tentang } \\
\text { metodologi penelitian yang } \\
\text { menyangkut siklus PTK dan alasan } \\
\text { pemilihan sampel }\end{array}$ & 10 & $100 \%$ \\
$6 \quad \begin{array}{l}\text { Masih minimnya uraian tentang } \\
\text { metodologi penelitian yang } \\
\text { menyangkut instrument penelitian dan } \\
\text { pengembangannya } \\
\text { Judul belum memuat teknik } \\
\text { pengajaran yang dipilih sebagai solusi } \\
\text { untuk masalah yang dihadapi }\end{array}$ & 9 & $90 \%$ \\
\end{tabular}

Table 1 diatas menunjukkan bahwa dari 6 masalah yang ditemukan dalam proposal PTK yang dihasilkan para peserta, terdapat 4 masalah krusial yg dominan terjadi pada hampir semua peserta.Kegiatan pengabdian yang akan dilakukan akan berfokus pada penyelesaian masalahmasalah diatas. Untuk itu kegiatan pengabdian yang dilakukan pada hari kedua tanggal 15 Agustus 2018 berfokus pada 4 masalah utama:

1. Penjelasan masalah yang diangkat dalam penelitian sebagai focus masalah dalam PTK.

2. Penguatan alasan pemilihan teknik sebagai solusi masalah yang dihadapi.

3. Penguatan landasan teoritis

4. Pendalaman metodologi penelitian terkait dengan desain PTK/siklus PTK, instrument dan pemilihan angket.

Poin-poin inilah yang kemudian menjadi bahasan utama dalam peningkatan menulis PTK bagi guru MTsN 2 Kab. Solok.

\section{Kegiatan post-test}

Dari data yang diperleh pada kegiatan pre-test, maka telah dilakukan pendampingan penulisan PTK pada peserta dengan berfokus pada 4 masalah utama yang dihadapi oleh peserta.

Setelah kegiatan pendampingan dilaksanakan, maka kembali dilakukan test penulisan proposal PTK dalam bentuk post-test untuk melihat perkembangan dan peningkatan yang diperoleh setelah kegiatan pendampingan. Berdasarkan hasil post-test yang dilakukan, diperoleh data sebagai berikut:

Table 2 Hasil Kegiatan Post-Test Peserta Dalam Penulisan Proposal PTK

\begin{tabular}{lll}
\hline Peserta & Masalah yang telah terselesaikan & Masalah yang masih perlu \\
pendampingan lebih lanjut
\end{tabular}

l a. Permasalahan yang diuraikan sudah spesifik pada permasalahan bidang speaking.

b. Sudah adanya alasan ilmiah dalam pemilihan teknik story telling dalam penyelesaian masalah speaking yang seharusnya tersaji pada bagian akhir a. Masih sangat minimnya teori yang digunakan sebagai landasan teoritis pada proposal yang ditulis. b. Masih minimnya uraian tentang metodologi penelitian yang terkait dengan pengembangan instrumen 
latar belakang masalah.

c. c. Sudah ada uraian tentang metode penelitian PTK, sampel penelitian dan siklus penelitian PTK.

a. Sudah adanya pernyataan solusi/ teknik pengajaran yang akan dipakai dalam penyesalaian masalah dalm judul yang diajukan.

b. Sudah adanya pernyataan yang spesifik tentang alasan memilih teknik mindmampping sebagai solusi masalah yang dihadapi.

c. Permasalahan yang terkait dengan tata bahasa pengutipan dan referensi dalam tulisan.

d. Sudah adanya informasi terkait dengan metode penelitian dan siklus PTK yang akan dilaksanakan. a. Judul sudah relevan dengan latar belakang masalah.

b. Masalah tentang kemampuan speaking siswa sudah dijabarkan dengan spesifik

c. Tidak adanya penjelasan lanjutan mengapa teknik jigsaw dipilih sebagai solusi dalam permasalahan speaking.

d. Sudah adanya teori yang digunakan sebagai landasan teoritis pada proposal

a. Sudah adanya penjelasan ilmiah mengapa teknik direct method dipilih sebagaisolusi dalam menyelesaikan masalah yang ada.

b. Metodologi telah dilengkapi sikus penelitian dan menjelaskan alasan pemilihan sampel.

a. Sudah ada penjelasan tentang permasalahan vocabulary dalam proses pembelajaran.

b. Metodologi penelitian belum membahas siklus PTK secara detail

a. Masalah telah diuraikan yang terkait dengan secara mendalam pada permasalahan listening/ kemampuan menyimak siswa.

b. Sudah ada bahasan tentang landasan teori sama sekali.

c. Sudah adanya uraian tentang metodologi penelitian yang dilakukan, apakah menggunakan PTK, kelas yang dipilih serta siklus a. Sangat minimnya teori yang digunakan sebagai landasan teoritis pada proposal.

b. Belum adanya penjelasan tentang instrument yang digunakan

a. Tidak adanya uraian tentang metodologi penelitian.

a. Masih kurangnya landasan teoritis dalam pengembangan proposal PTK.

b. metodlogi masih belum memuat tentang instrument penelitian.

a. Teori yang digunakan baru membahas secara umum tentang guess word (masih sangat terbatas) b. Belum ada penjelasan tentang instrument penelitian PTK a. Belum adanya uraian tentang instrument yang digunakan. 
7

8

9

10 pelaksanaan PTK

a. Masalah sudah diuraiakan secara spesifik kearah kemampuan speaking dalam menjelaskan procedure text.

b. Landasan teoritis sudah ada walaupun masih butuh pengembangan

c. Metodologi sudah memuat bentuk penelitian adalah PTK dan siklus PTK.

a. Masalah yang diuraikan sudah membahas masalah reading comprehension

b. Sudah adanya penjelasan ilmiah kenapa teknik number heads together dipakai sebagai solusi masalah yang ada

c. Landasan teoritis sudah membahas konsep reading dan teori tentang teknik number heads together.

d. Masih belum jelasnya metode pelaksanaan penelitian PTK berupa siklus penelitian.

a. Sudah adanya penjelasan tentang mengapa teknik tersebut dipilih untuk menjadi solusi masalah yang ada.

b. Sudah adanya penjelasan metodologi penelitian.

a. Sudah adanya landasan teori yang digunakan.

b. Sudah adanya penjelasan instrument yang akan digunakan pada pelaksanaan PTK. a. Belum adanya uraian tentang instrument yang digunakan

a. Masih belum adanya penjelasan instrument yang dipakai.
Tidak adanya landasan teori dalam proposal

Dari table 2 diatas, diketahui bahwa masalah yang dihadapi oleh peserta dalam kegiatan pre-test sudah teratasi melalui kegiatan pendampingan walaupun masih menyisakan beberapa masalah yang harus ditindaklanjuti.

Data pada table 2 menunjukkan pengelompokan masalah yang telah terselesaikan dan masalah yang masih membutuhkan tindak lanjut. Berikut dimuat klasifikasi permasalahan tersebut yang dimuat pada Table 3

Table 3 Hasil Kegiatan Pendampigan terhadap Masalah yang Dihadapi Peserta dalam Penulisan Proposal PTK

\begin{tabular}{cll}
\hline No & Masalah yang Telah Terpecahkan & Masalah yang Butuh Follow-Up \\
\hline $\mathbf{l}$ & $\begin{array}{l}\text { Relevansi antara judul dan masalah } \\
\text { yang dibahas }\end{array}$ & $\begin{array}{l}\text { Minimnya landasan teoritis yang digunakan } \\
\text { dalam proposal }\end{array}$ \\
2 & $\begin{array}{l}\text { Judul sudah memuat teknik } \\
\text { pengajaran yang dipilih sebagai solusi }\end{array}$ & $\begin{array}{l}\text { Masih minimnya uraian tentang metodologi } \\
\text { penelitian yang menyangkut instrumen }\end{array}$
\end{tabular}




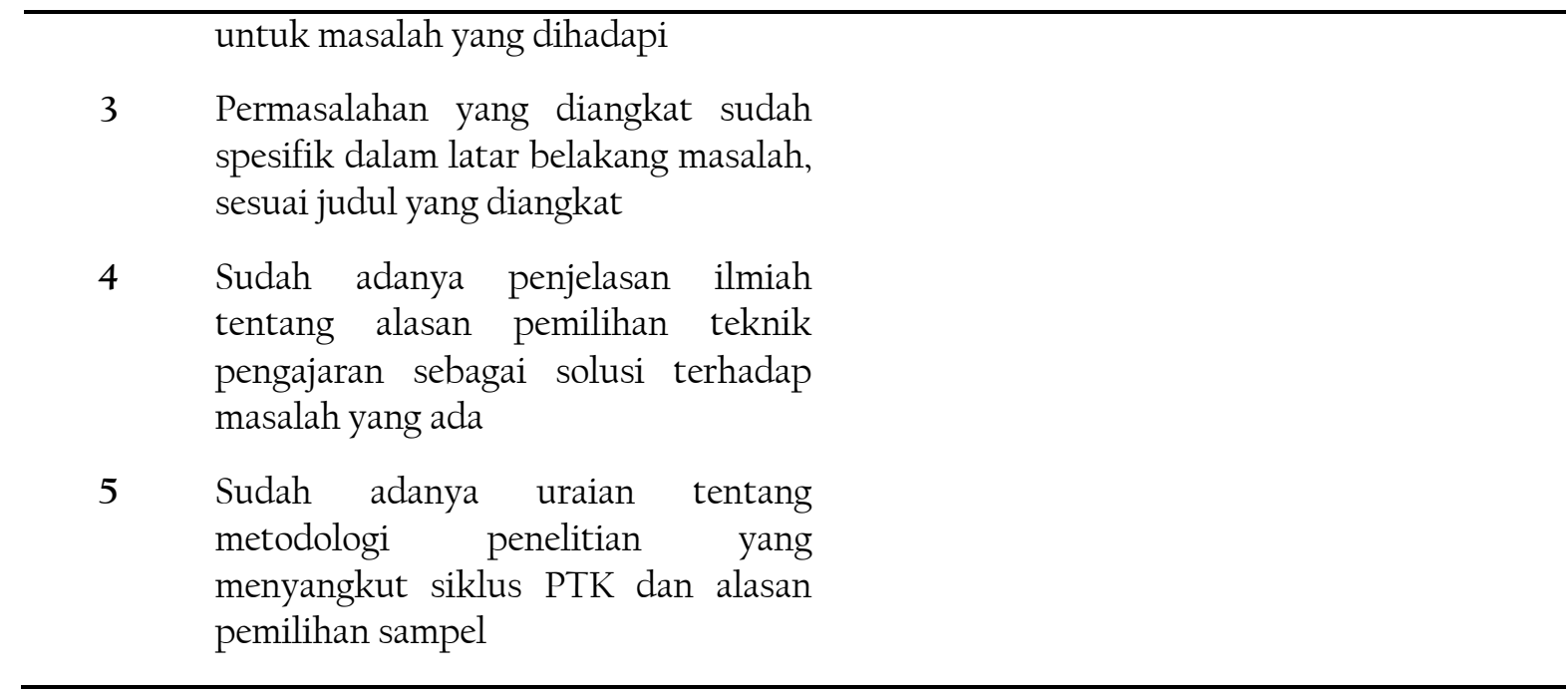

Dari table 3 diatas dapat diketahui bahwa adanya peningkatan kemampuan menulis proposal PTK yang sebelumnya terdiri dari 7 masalah dan telah terselesaikan 5 dari 7 masalah tersbeut. Dengan kata lain, kegiatan pendampingan ini telah menunjukkan peningkatan kemampuan peserta sebesar $72 \%$.

\section{Discussion}

Peningkatan yang terkategori tinggi dalam kemampuan guru menulis PTK menjadi sebuah indikator positif terhadap keberhasilan pelaksanaan pelaksanaan pengabdian masyarakat dalam bentuk pendampingan penulisan PTK bagi guru bahasa inggris. Chisman dan Crandall (2007) menegaskan bahwa kegiatan pemberdayaan dan pendampingan peningkatan kualitas pengajaran guru merupakan suatu hal yang penting untuk dilakukan guru serta pihak terkait guna meningatkan kualitas pengajaran guru[11]. Lebih lanjut, Chisman dan Crandall (2007) juga mnenyebutkan bahwa kegiatan pemberdayaan dan pendampingan yang diberikan untuk guru akan membawa hasil positif yang bagus bagi peningkatan kompetensi guru[1l]. Hal ini disebabkan oleh kegiatan pemberdayaan dan pendampigan yang diperoleh guru pada dasarnya lebih menekankan pada pengenalan teori serta aplikasi teknik pengajaran yang up to date. Hal ini tentunya membawa dampak positif pada guru dalam proses pembelajaran. Guru yang memiliki lebih banyak ilmu dan teori tentang teknik pengajaran lebih berpeluang untuk menerapkan teknik pengajaran tersebut dalam proses pembelajaran. Berdasarkan uraian tersebut, dapat disimpulkan bahwa keberhasilan pelaksanaan kegiatan pengabdian masyarakat dalam bentuk pendampingan menulis PTK bagi guru bahasa inggris menjadi sebuah indikasi positif untuk peningkatan kemampuan dan kompetensi guru dalam mengajar ke depannya.

Lebih lanjut, Menurut Sparks dalam Murray (2010), guru wajib melakukan kegiatan pemberdayaan diri guna meningkatkan kemampuan mengajar yang pada akhirnya bermuara pada peningkatan kualitas peserta didik. Murray (2010) menyatakan ada setidaknya 6 langkah yang bisa dilakukan 
guru untuk peningkatan kualitas kompetensi mengajar, salah satunya melalui pelaksanaan PTK. Oleh sebab itu, pelaksanaan PTK menjadi sebuah urgensi bagi guru sehingga diharapkan hasil belajar yang lebih baik untuk para peserta didik setelah para guru mampu meningkatkan kualitas pengajaran dan pembelajaran melalui pelaksanaan PTK.

Pentingnya keberhasilan pelaksanaan pengabdian ini menjadi suatu hal yang urgen mengingat pelaksanaan PTK oleh guru membawa manfaat tidak hanya dalam peningkatan kualitas belajar peserta didik secara langsung, tapi juga membawa manfaat yang lainnya. Asrori (2008) menyatakan bahwa setidaknya da dua manfaat penting yangd iperoleh guru ketika guru behrasil melaksanakan PTK, yaitu kemampuan guru akan meningkatan untuk membuat inovasi-inovasi terbaru dalam desain pembelajaran[4]. Hal ini tentu saja mengarah pada peningkatan profesionalisme guru sebagai profesi yang bertujuan untuk meningkatkan kualitas kecerdasan bangsa. Manfaat yang kedua yaitu keberhasilan guru dalam melaksanakan PTK akan memberi kontribusi pada pengembangan kurikulum secara umum. Kurikulum yang diterapkan pada system pendidikan tentunya didasarai oleh kebutuhan siswa terhadap pendidikan. oleh sebab itu, setiap tindakan yang diambil guru dalam PTK akan memberikan kontribusi terhadap pengmebangna dna perbaikan kurikulum ke depannya. Berdasarkan uraian diatas, maka dapat dinyatakan bahwa kemampuan guru dalam melaksanakan PTK menjadi salah satu penentu keberhasilan duania pendidikan secara umum, dan menjadi penentu keberhasilan peserta didik dalam proses pembelajaran secara khususnya. Oleh karena itu, kegiatan pendampingan menulis PTK pada guru menjadi salah satu usaha yang penting dalam meningkatkan kemampuan guru untuk melaksanakan PTK tersebut.

\section{Conclusion}

Berdasarkan proses pelaksanaan kegiatan pengabdian masyarakat dalam bentuk pendampingan penulisan karya ilmiah berupa PTK, yang telah dilaksanakan selama 3 hari pendampingan yakni 14-16 Agutsus 2018, dapat disimpulkan beberapa hal, yaitu:

1. Sebelum dilaksanakannya proses pendampingan penulisan PTK, guru-guru bahasa inggris mengalami permasalahan penulisan proposal PTK yang terkait dengan relevansi judul dan masalah, pemilihan masalah yang akan diangkat dalam penelitian, pemilihan teknik pengajaran sebagai solusi terhadap masalah yang ada, minimnya landasan teoritis yang dimiliki guru, serta dangkalnya pemahaman tentang metodologi penelitian, khususnya penelitian PTK.

2. Setelah diadakannya proses pendampingan PTK, guru-guru bahasa inggris mampu mengurai beerapa maalah yang dihadapi, yaitu masalah yang terkait dengan relevansi judul dan masalah, ketepatan penmilihan teknik pengajaran dengan masalah yang ada, pengembangan pemahaman guru tentang prosedur pelaksanaan PTK yang menyangkut siklus PTK serta pemilihan sampel dalam penelitian.

3. Selain masalah yang dapat diselesaikan melalui kegiatan pengabdian masyarakat dalam bentuk pendampingan penulisan proposal PTK ini, juga diperoleh simpulan yang merujuk pada 
perlunya tindakan lanjutan terkait dnegna pengembangan keilmuan guru dalam membuat instrumen yang tepat untuk pelaksanaan PTK serta penguatan fondasi kajian teoritis sebagai landasan ilmiah dalam melaksanakan penelitian. Guru-guru bahasa inggris belum memiliki referensi dan rujukan yang cukup banyak terkait dengan kajian teoritis dalam bidang pengajaran bahasa inggris serta kajian mendalam terkait metodologi penelitian PTK.

Berdasarkan poin kesimpulan diatas maka dapat dinyatakan bahwa pelaksanaan pengabdian masyarakat dengan tujuan untuk memberikan pendampingan penulisan karya ilmiah dalam bentuk penulisan PTK dikategorikan cukup berhasil. Hal ini ditunjukkan dengan adanya peningkatan yang cukup signifikan dalam penyelesaian masalah yang dihadpai guru dalam menulis PTK.

\section{Bibliography}

[1] Depdiknas, Permendiknas Nomor 16 tahun 2007 tentang Standar Kompetensi Guru. Jakarta: Depdiknas, 2007.

[2] Depdiknas, Peraturan Pemerintah Nomor 19 tahun 2005 tentang Standar Nasional Pendidikan. Jakarta: Depdiknas, 2005.

[3] and D. N. Bailey, K., A. Curtis, Pursuing professional development: The self assource. Ontario: Heinle and Heinle, 2001.

[4] M. Asrori, Penelitian Tindakan Kelas. Bandung: CV Wacana Prima, 2008.

[5] \& S. Arikunto, S, Suhardjono, Penelitian Tindakan Kelas. Jakarta: Bumi Aksara, 2006.

[6] Depdiknas, Undang-undang No. 14 tahun 2005 tentang Guru dan Dosen. Jakarta: Depdiknas, 2005.

[7] A. Jordan, M \& Herrel, 50 Strategies for Teaching English Language Learners. New Jersey: Pearson Merril Prentice Hall., 2008.

[8] R. Kemmis, S. \& Mc. Taggart, The Action Research Planner. Victoria: Deakin University Press, 1992.

[9] M. H. Furtrell, "Empowering teachers as learners and leaders," in Teachers as leaders: Perspectives on the professional development ofteachers, Bloomington: Phi Delta Kappan Educational Foundation, 1994, pp. 119-136.

[10] L. Johnson, Pengajaran yang Kreatif dan Menarik. Jakarta: PT Macanan Jaya Cemerlang, 2008.

[11] and J. A. C. Chisman, F. P., Passing the torch: Strategies for innovation incommunity college ESL. New York: Council for Advancement of Adult Literacy, 2007.

[12] S. T. Celce-Murcia, M., Z. Dornyei, "Communicative Competence: A Pedaogically 
Motivated Model with Content Specifiations," Issues Appl. Linguist., vol. 6, no. 2, 1995.

[13] and K. A. Galbraith, P., "Peer coaching: An effective staff development modelfor educators of linguistically and culturally diverse students," 1995. .

[14] Kunandar, Langkah-Langkah Penelitian Tindakan Kelas. Jakarta: PT.Raja Grafindo Persada, 2008.

[15] M. Nur, Penelitian Tindakan Kelas (konsep dasar dan langkah-langkah PTK). Departemen Pendidikan Nasional Universitas Negeri Surabaya PSMS Pascasarjana, 2001.

[16] S. Kardi, Penelitian Tindakan Kelas. Kumpulan Makalah Teori Pembelajaran MIPA. Departemen Pendidikan Nasional Universitas Negeri Surabaya PSMS Pascasarjana., 2000 . 